\title{
Frequency of Sella Turcica Bridge and Clinoid Enlargement in Lateral Cephalometric Plain Film Radiography from Peruvians
}

\author{
Frecuencia de Puente Selar y Alargamiento Clinoideo en \\ Radiografías Cefalométricas Laterales de Peruanos
}

Iván E. Pérez*; Allison K. Chávez** \& Darío Ponce****

PÉREZ, E. I.; CHÁVEZ, K. A. \& PONCE, D. Frequency of sella turcica bridge and clinoid enlargement in lateral cephalometric plain film radiography from Peruvians. Int. J. Morphol., 31(2):373-377, 2013.

SUMMARY: The purpose for the present study was to determine the frequency of sella turcica bridge and clinoid enlargement on lateral cephalometric plain film radiography from peruvians patients who attended our radiological center and identify any possible genre or age group associations. The sella turcica from 417 lateral cephalometric plain film radiography was evaluated in order to determine the presence of sella turcica bridge (fusion between the anterior and posterior clinoid process) or clinoid enlargement related to the Sella (S) cephalometric point. The sella turcica bridge and clinoid enlargement frequency was $4.31 \%(\mathrm{n}=18)$, and $16.3 \%(\mathrm{n}=68)$. Cramer's V and ETA statistics found, by separately, non significant association ( $p>0.05)$ between sella turcica bridge and clinoid enlargement with respect to sex, and age groups (under 18 and over 18). The sella turcica bridge and clinoid enlargement are not so infrequent findings in the population studied, our results are similar to those reported in the literature. The existence of a sella turcica bridge or a clinoid enlargement must be considered as a structural anomaly that may influence the prognosis of surgical procedures of the sella turcica.

KEY WORDS: Sella turcica; Radiology; Pathology; Ossification/ heterotopic; Calcinosis

\section{INTRODUCTION}

The sella turcica in the sphenoid bone consists of a central hypophysial fossa and two pair of clinoid processes (anterior and posterior). Those processes are connected by a horizontal fold of dura mater described as interclinoid dural fold (Ozdogmus et al., 2003), interclinoid ligament (Ozdogmus et al.,; Archana et al., 2010; Suazo-Galdames et al., 2008), fibrous ligament (Cedeberg et al., 2003) or diaphragma sellae (Butler, 2006) that margins superiorly the sella turcica like an incomplete dural roof (Butler), separating it from the suprasellar subaracnoid space (CastriotaScandenberg, 2005) and, sometimes, is the back-ground of partial or complete ossification (Archana et al.; SuazoGaldames et al.; Skrzat et al. 2006), with the conformation of an osseous structure like a bony bar or thick bony trabecula (Skrzat et al.), and the appearance of a separate enclosed pituitary fossa (Kantor \& Norton, 1987) with a foramina below named common interclinoid foramen (Archana et al., 2010). That osseous structure has been termed differently in the literature: interclinoid taenia (Ozdogmus et al.), iaenia interclinoidea (Lang, 2001), Interclinoid bars (Archana et al.; Skrzat et al.), interclinoid osseous bridge (Ertuk et al., 2004), sella turcica bridge/bridging (Jones et al., 2005; Archana et al.; Leonardi et al., 2006; Leonardi et al., 2009; Leonardi et al., 2011; Meyer-Marcotty et al., 2010), sella bridge (Peker et al., 2006), roofing/bulging/calcification of the diaphragma sellae (Kantor \& Norton; Leonardi et al., 2009; Leonardi et al., 2011; Leonardi et al., 2006), Calcified/ ossified interclinoid ligament (Cedeberg et al.; Ozdogmus et al.; Skrzat et al.), and Bridged sella (Cedeberg et al.; Tetradis \& Kantor, 1999).

The only way of diagnosing any calcification of the sella turcica is with a lateral skull - cephalometric radiography (Leonardi et al., 2011). The sella turcica bridge (STB) is the true bony union of the anterior and posterior clinoid processes (Leonardi et al., 2011); the clinoid

\footnotetext{
* Radiología Oral. Centro para la investigación de las disarmonías dentofaciales (CIDDENT), Lima Perú.

** Universidad Peruana Cayetano Heredia. Facultad de Estomatología. Departamento de Clínica Estomatológica, Lima Perú.

**** Estadística. Centro para la investigación de las disarmonías dentofaciales (CIDDENT), Lima Perú.
} 
enlargement (CLEN), is the overlapping (a projectional artifact) of the anterior and posterior clinoid processes (Axelsson et al., 2004; Becktor et al., 2000) and not necessarily real bony fusion (Becktor et al.). But a clear distinction between sella turcica bridge (STB) and clinoid enlargement (CLEN) on lateral radiographs is difficult to determine (Axelsson et al.; Leonardi et al.).

The purpose for the present study was to determine the frequency of sella turcica bridge and clinoid enlargement in lateral cephalometric radiography from Peruvians, identify any possible sex difference and age group associations and compare our findings with similar studies in the scientific literature.

\section{MATERIAL AND METHOD}

Conventional (plain film) lateral cephalometric radiography of 463 Peruvians patients from Lima - Perú who attended our radiology center (CIDDENT) between January - May 2011 were evaluated to determine the presence of sella turcica bridge (STB) and clinoid enlargement (CLEN). To obtain data from a normal population, lateral cephalometric radiography from any cleft palate patients, craneofacial syndromes, and poor quality image were excluded from the present study.

The sella turcica region was reviewed by a maxillofacial radiologist (IEPL) and the findings were classified as follows:

a. Sella turcica bridge (STB), presence of a continuous bony bar between anterior and posterior clinoid processes with a delimited round cavity below and the appearance of a separate enclosed hypophysial fossa (Kantor \& Norton,). (Fig. 1).

b. Clinoid enlargement (CLEN), anterior or posterior clinoid

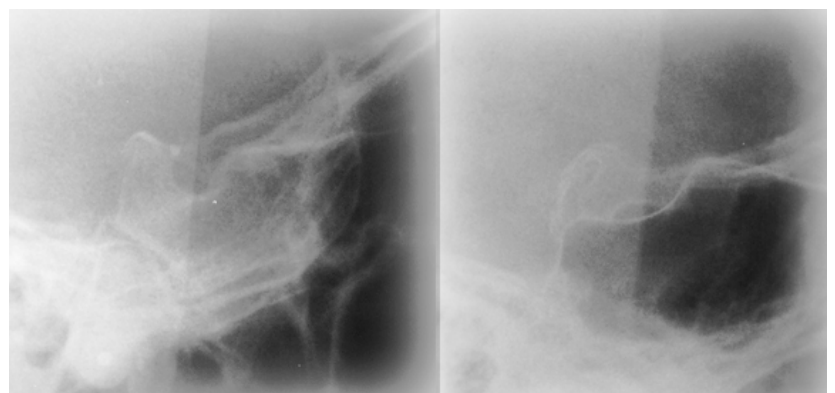

Fig. 1. Sella turcica bridge (STB) examples, notice the bony bar between the clinoid processes. processes enlargement that surpasses the Sella (S) cephalometric point. (Fig. 2).

c. Negative finding.

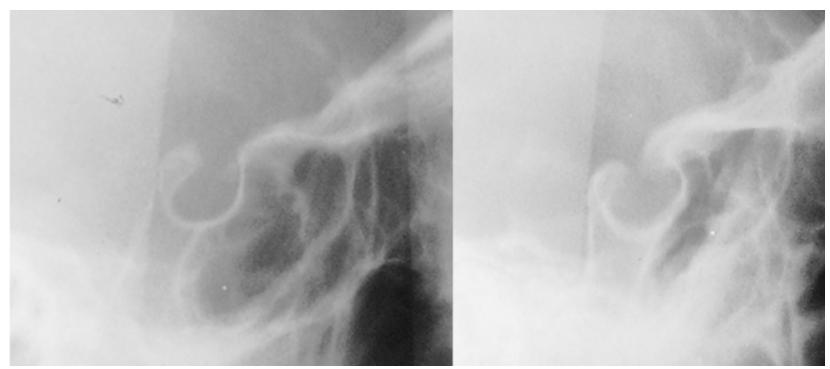

Fig. 2. Clinoid enlargement related to S (Sellae point) examples.

Database was grouped in MS Office Excel 97 and statistical analyses were performed on IBM SPSS Statistics 15. The statistical comparisons included Cramer's V statistics and ETA statistics to evaluate the association degree between STB and CLEN with sex and age groups (under 18 and over 18) variables. The significance level was set at $\mathrm{p}<0.05$.

To determine intraexaminer agreement in the identification of sella turcica bridge or pseudobridging, 100 lateral cephalometric radiographs were re-evaluated by the maxillofacial radiologist two weeks after the initial analysis; Kappa coefficient value was 0.889 which means a substantial strength of agreement (Sim \& Wright, 2005).

\section{RESULTS}

From the initial population study (463 lateral cephalometric radiography), forty six were excluded because they met the exclusion criteria described above. After all, 417 lateral cephalometric radiography were able to be evaluated.

Of the 417 radiography, 239 were from females and 178 from males. The age range was $5-53$ years with a mean value of $14.73+/-7.83 ; 15.03+/-8.45$ for females and 14.32 $+/-6.92$ for males.

The STB frequency was $4.3 \%$ (1.91\% in females, $2.39 \%$ in males, $2.63 \%$ in the 5 to 18 years group and $1.67 \%$ in the 19+ years group), and the CLEN frequency was $16.3 \%$ (13.31\% in females, $5.99 \%$ in males, $12.7 \%$ in the 5 to 18 years group and $3.6 \%$ in the $19+$ years group). Cramer's V 
statistics and ETA statistics association indexes were calculated to test whether the distribution of STB and CLEN were statistically significative associated to sex and age groups, the results were not significant ( $\mathrm{p}>0.05)$. (Tables I, II).

Table I.Distribution of STB and CLEN according to sex.

\begin{tabular}{llcccr}
\hline & & \multicolumn{3}{c}{ Sella turcica } & Total \\
\cline { 3 - 5 } & & No finding $(\%)$ & Bridge $(\%)$ & CLEN(\%) & \\
\hline Sex & Female & $188(45,08)$ & $8(1,91)$ & $43(10,31)$ & 239 \\
& Male & $143(34,29)$ & $10(2,39)$ & $25(5,99)$ & 178 \\
\hline Total & & 331 & 18 & 68 & 417 \\
\hline
\end{tabular}

Cramer's V statistics value $=0,073(\mathrm{p}>0.05)$

Table II.Distribution of STB and CLEN according to age groups.

\begin{tabular}{cccccc}
\hline & & \multicolumn{3}{c}{ Sella Turcica } & \multirow{2}{*}{ Total } \\
\cline { 3 - 5 } & & No finding(\%) & Bridge(\%) & CLEN(\%) & \\
\hline \multirow{3}{*}{ Age groups } & to $18 \mathrm{y}$ & $279(66.9)$ & $11(2.63)$ & $53(12.7)$ & 343 \\
& $($ mean$)$ & 11,5 & 11,3 & 12,8 & 11,7 \\
\cline { 2 - 5 } & $19+$ & $52(12.47)$ & $7(1.67)$ & $15(3.6)$ & 74 \\
\hline Total & $($ mean $)$ & 29,8 & 23,3 & 28,2 & 28,9 \\
\hline
\end{tabular}

Eta statistics value $=0,110 *(p>0.05)$

\section{DISCUSSION}

The radiographic diagnosis of STB and CLEN was made according to the criteria found in the literature (Kantor \& Norton; Meyer-Marcotty; Becktor et al., 2000). For CLEN an extra criterion was set: the relationship between the enlarged clinoid process tip with the sella cephalometric point (S), which is an adequate and easy-to-find radiographic reference point; such criteria and reference point for CLEN has not been used or proposed before. Axelsson et al., used the relationship between two reference lines (sella turcica length and diameter) to diagnose CLEN; Leonardi et al. (2006, 2009 and 2011) use the same criteria. Becktor et al., diagnose CLEN if the tip of the clinoid processes extend and meet anteriorly, posteriorly or in the middle with a thinner fusion. Cedeberg et al., quantified the extent of ligamentous calcification in less than a half and more than a half calcification. Jones et al., use the interclinoid distance to diagnose CLEN.

Cephalometric radiography and tracings are used in orthodontics to evaluate the craniofacial and dental structures, but they also include other diagnostics information about the skull, face, and upper cervical spine (Leonardi et al., 2009; Leonardi et al., 2006), and various occult pathologies and rare normal variants involving the head or spine have been reported thanks to this information (Leonardi et al., 2009). Plain film radiography have a relatively high sensitivity for detecting sella change at between $67 \%$ and $77 \%$ of positive findings (Jones et al.,); and the lateral cephalometric radiography may give initial evidence of pathology in the sella turcica region (Meyer-Marcotty). The sella turcica is an area of the skull commonly viewed by orthodontists during radiographic interpretation prior to cephalometric analysis (Cedeberg et al.).

The STB frequency found in our study was $4.31 \%$ (3.3\% females and 5.6\% males), and the CLEN frequency was $13.6 \%$ ( $17.9 \%$ females and $14 \%$ males); with no statistical differences between sex and age groups. The STB and CLEN frequencies found in the present study are similar to those found by Bektor et al., STB frequency of 5.6\% and CLEN frequency of $13 \%$; Axelson et al,, STB frequency of 5.6\% (6\% in males and 16\% in females); and Cederberg et al., STB frequency of $8.2 \%$ and CLEN frequency of $38.4 \%$, the CLEN frequency found in the present study is markedly lower. Jones et al., found a STB frequency of $6.68 \%$ and $4.64 \%$ in two different groups of patients (combined surgical-orthodontical correction, and orthodontic correction only), and a CLEN frequency of $10.02 \%$ and $2.65 \%$ too, with statistically significant differences between the two groups, our findings are similar but the inclusion 
criteria regarding population between the studies are different, also it has been reported that the STB are rarer than CLEN (Peker et al.,) but this not met according to the results in the orthodontic correction only. Tetradis \& Kantor found a STB frequency of $11 \%$; the STB frequency found in our study is lower. Meyer-Marcoty et al.,(2010) found a STB frequency in class I skeletal patients of $0.7 \%$ and the CLEN frequency of $8.7 \%$. In class III skeletal patients, the STB frequency was $0.4 \%$ and the CLEN frequency was $16.4 \%$, the differences were not statistically significant, the STB frequency found in our study is markedly higher for both groups of patients; the CLEN frequency found in our study is similar for both groups of patients.

A greater frequency of STB has been described in patients with severe craniofacial deviations and tooth anomalies (Leonardi et al., 2009; Becktor et al.; Leonardi et al., studied the relationship between STB/CLEN with dental anomalies (2006), palatally displaced canines (2009) and canine transposition (2011); and their results demonstrate an increased prevalence, with a statistically significative difference between cases and controls of STB and CLEN in patients with palatally displaced canines, dental anomalies and canine transposition. The results of the present study are similar in respect to frequency differences between STB and CLEN (the latter is always more frequently).

The knowledge of structural abnormalities is essential for safety in surgical management (Skratz et al.); the variations in the clinoid processes and the detailed anatomy of the interclinoid ligament should be carefully studied by neurosurgeons, especially because this could increase the success of surgical approaches to the region (Ozdogmus et $a l$.). For any surgery involving the anterior clinoid process, preoperative imaging may be advised, to keep such anomalies in view (Das et al., 2007).

The STB may influence structures like the internal carotid and the opthalmic artery, the optic, throclear
(Hunnargi et al., 2008) and oculomotor (Skratz et al.) nerves, and the pituitary gland (Cedeberg et al., 2003), but in the absence of clinical signs or symptoms it is considered a normal variant of the sella turcica, although many pathological processes can be associated with this calcification (Leonardi et al., 2006).

The anterior clinoidectomies has been used by surgeons to gain access to the clinoid space (Shipra \& Das, 2007), suprasellar and parasellar regions (Hunnargi et al., 2008) and the cavernous sinus, (Shipra \& Das; Hunnargi et $a l$.), and is one of the most critical procedures for the successful management of aneurysms of the carotidopthalmic artery, the internal carotid artery, the intracavernous internal carotid artery, the upper basilar artery, and for tumors of the clinoid region (Hunnargi et al.).

The posterior clinoidectomies has been used to approach the upper basilar region and the posterior aspect of the hypophysial fossa (Shipra \& Das), to expose a length of basilar artery that includes its bifurcation (Shipra \& Das), and to expose the clinoid segment of the internal carotid artery (Das et al.).

The presence of a STB makes the anterior clinoidectomies difficult by increasing the risk to damage adjacent important structures (Archana et al.), and rupturing or tearing the internal carotid artery which leads to cerebral infarction especially if an aneurysm is present (Ertuk et al.; Peker et al.).

In conclusion, the STB and CLEN are not so infrequent radiographic findings in Peruvians, and their frequencies found in the present study are similar to the studies found in the literature; no statistically significant associations were found. The relationship between the enlarged clinoid process tip and the Sella (S) cephalometric point can be used to determine and standardize the finding of CLEN.

PÉREZ, E. I.; CHÁVEZ, K. A. \& PONCE, D. Frecuencia de puente selar y alargamiento clinoídeo en radiografías cefalométricas laterales de peruanos. Int. J. Morphol., 31(2):373-378, 2013.

RESUMEN: El propósito del estudio fue determinar la frecuencia de puente selar y alargamiento clinoideo en radiografías laterales cefalométricas de pacientes peruanos que asistieron a nuestro centro radiográfico entre enero a mayo del 2011 e identificar posibles asociaciones de sexo ó edad. El área de la silla turca de 417 radiografías cefalométricas laterales fue evaluada para determinar la presencia de puente selar (fusión entre los procesos clinoides) o alargamiento de los procesos clinoides anterior o posterior en relación con el punto cefalométrico Sella (S). La frecuencia de puente selar fue de 4.31\% (n=18), la frecuencia de alargamiento clinoideo fue de 16.3\% ( $\mathrm{n}=68$ ). Los análisis estadísticos $\mathrm{V}$ de Kramer y ETA no encontraron asociación significativa entre el puente selar y alargamiento clinoideo con respecto al sexo y a la edad ( $>$ >0.05). El puente selar y el alargamiento clinoideo no son hallazgos radiográficos tan infrecuentes en la población estudiada; nuestros resultados son similares a los encontrados en la literatura. La presencia del puente selar y alargamiento clinoideo debe tenerse en cuenta como una anomalía estructural que puede influir en el pronóstico de los procedimientos quirúrgicos en la zona de la silla turca.

PALABRAS CLAVE: Silla turca; Radiología; patología; Osificación heterotópica; Calcinosis. 


\section{REFERENCIAS BIBLIOGRÁFICAS}

Archana, R.; Anita, R.; Jyoti, C.; Punita, M. \& Rakesh, D. Incidence of osseous interclinoid bars in Indian population. Surg. Radiol. Anat., 32(4):383-7, 2010.

Axelsson, S.; Storhaug, K. \& Kjaer, I. Post-natal size and morphology of the sella turcica. Longitudinal cephalometric standards for Norwegians between 6 and 21 years of age. Eur. J. Orhod., 26(6):597-604, 2004.

Becktor, J. P.; Einersen, S. \& Kjaer, I. A sella turcica bridge in subjects with severe craniofacial deviations. Eur. J. Orthod., 22(1):69-74, 2000.

Buttler, P.; Mitchell, A. \& Ellis, H. Editors. Applied radiological anatomy. $1^{\text {a }}$. ed. Cambridge, United Kingdom, Cambridge University Press, 2006.

Castriota-Scandenberg, A. \& Dallapicolla, B. Abnormal skeletal phenotypes: from simple signs to complex diagnoses. Würzburg, Germany, Springer, 2005.

Cedeberg, R. A.; Benso, B. W.; Nunn, M. \& English, J. D. Calcification of the interclinoid and petroclinoid ligaments of sella turcica: a radiographic study of the prevalence. Orthod. Craniofac. Res., 6(4):227-32, 2003.

Das, S.; Suri, R. \& Kapur, V. Ossification of caroticoclinoid ligament and its clinical importance in skull-based surgery. São Paulo Med. J., 125(6): 351-3, 2007.

Ertuk, M.; Kayalioglu, G. \& Govsa, F. Anatomy of the clinoidal region with special emphasis on the caroticoclinoid foramen and interclinoid osseous bridge in a recent Turkish population. Neurosurg. Rev., 27(1): 22-6, 2004.

Hunnargi, S.; Ray, B.; Pai, S. R. \& Siddaraju, K. S. Metrical and non-metrical study of anterior clinoid process in South Indian adult skulls. Surg. Radiol. Anat., 30(5):423-8, 2008.

Jones, R. M.; Faqir, A.; Millet, D. T.; Moos, K. F.; McHugh, S. Bridging and dimensions of sella turcica in subjects treated by surgical-orthodontics means or orthondontics only. Angle Orthod., 75(5):714-8, 2005.

Kantor ML, Norton LA. Normal radiographic anatomy and common anomalies seen in cephalometric films. Am. J. Orthod. Dentofacial Orthop., 91(5):414-26, 1987.

Lang J. Skull base and related structures: atlas of clinical anatomy. 2. ed. Stuttgart, Germany, Schattauer GmbH, 2001.

Leonardi, R.; Barbato, E.; Vichi, M. \& Caltabiano, M. Skeletal anomalies and normal variants in patients with palatally displaced canines. Angle Orthod., 79(4):727-32, 2009.
Leonardi, R.; Farella, M. \& Cobourne, M. T. An Association between sella turcica bridging and dental transposition. Eur. J. Orthod., 33(4): 455-461, 2011.

Leonardi, R.; Barbato, E.; Vichi, M. \& Caltabiano, M. A sella turcica bridge in subjects with dental anomalies. Eur. J. Orthod., 28(6): 580-585, 2006.

Meyer-Marcotty P, Reuther T, Stellzig-Eisenhauer A. Bridging of the sella turcica in skeletal Class III subjects. Eur. J. Orthod., 32(2):148-53, 2010.

Ozdogmus, O.; Saka, E.; Tulay, C.; Gurdal, E.; Uzun, I. \& Cavdar, S. Ossification of interclinoid ligament and its clinical significance. Neuroanatomy, 2(1): 25-27, 2003.

Peker, T.; Anil, A.; Gülekon, N.; Turgut, H. B.; Pelin, C. \& Karaköse, $\mathrm{M}$. The incidence and types of sella and sphenopetrous bridges. Neurosurg. Rev., 29(3): 219-23, 2006.

Shipra, P. \& Srijit, D. Anomalous posterior clinoid process and its clinical importance. Colomb. Med., 38(3): 301, 2007.

Sim, J. \& Wright, C. C. The kappa statistic in reliability studies: use, interpretation, and sample size requirements. Phys. Ther., 85(3):257-68, 2005.

Skrzat J, Szewczyk R, Walocha J. The ossified interclinoid ligament. Folia Morphol. (Warsz)., 65(3):242-5, 2006.

Suazo-Galdames, I.; Zavando-Matamala, D. \& Smith, R. Ossification of the Sella Turcica and Clinoid Ligaments: Case Report, Morphological Study and Literature Review. Int. J. Morphol., 26(4):799-801, 2008.

Tetradis, S. \& Kantor, M. L. Prevalence of skeletal and dental anomalies and normal variants seen in cephalometric and other radiographs of orthodontic patients. Am. J. Orthod. Dentofacial Orthop., 116(5):572-7, 1999.

\author{
Correspondence to: \\ Dr. Iván Pérez \\ Centro para la investigación de las disarmonías dentofaciales \\ (CIDDENT) \\ Lima \\ PERÚ
}

Email: iepl76@yahoo.com

Received: 24-04-2012

Accepted: 20-01-2013 